\title{
Papillibacter cinnamivorans gen. nov., sp. nov., a cinnamate-transforming bacterium from a shea cake digester
}

\author{
S. Defnoun, ${ }^{1,2}$ M. Labat, ${ }^{1}$ M. Ambrosio, ${ }^{2}$ J.-L. Garcia and B. K. C. Patel ${ }^{3}$
}

Author for correspondence: B. K. C. Patel. Tel: +61417 726671. Fax: +61738757800.

e-mail: bharat@genomes.sci.gu.edu.au

1 Laboratoire IRD de Microbiologie, Université de Provence - CESB/ESIL Case 925, 163 Avenue de Luminy, 13288 Marseille Cedex 9, France

2 Laboratoire Chimie et Environnement, Université de Provence, 3 Place Victor Hugo, 13331 Marseille, Cedex 3, France

3 School of Biomolecular and Biomedical Sciences, Faculty of Science, Griffith University, Brisbane, Queensland 4111, Australia
A new, strictly anaerobic, Gram-positive, non-sporulating, mesophilic bacterium, designated strain $\mathrm{CIN1}^{\mathrm{T}}$ ( $\mathrm{T}=$ type strain) was isolated from an anaerobic digester fed with shea cake rich in tannins and aromatic compounds. Cells of strain $\mathrm{CIN1}^{\mathrm{T}}$ were rod-shaped, had characteristically pointed ends (1.3-3.0 $\times 0.5-0.6 \mu \mathrm{m})$ and occurred singly, in pairs and sometimes in chains of up to six. The pH range for growth was 6.9-8.5 and the temperature growth range was $15-40^{\circ} \mathrm{C}$. Optimum growth occurred with yeast extract and cinnamate at $37^{\circ} \mathrm{C}$ and a pH of 7.5. The isolate transformed cinnamate by degrading the aliphatic side chain to produce acetate and benzoate rather than by aromatic ring cleavage or demethoxylation. The position of the methoxyl group appears to be important in the degradation of the aliphatic side chain of cinnamate; consequently, 3-methoxycinnamate and 4-methoxycinnamate, but not 2-methoxycinnamate, are transformed to produce acetate and methoxybenzoates, namely 3-methoxybenzoate and 4-methoxybenzoate, respectively. Crotonate is degraded to acetate and butyrate. The G+C content of the DNA is 56 mol\%. Phylogenetic analysis of the 16S rRNA gene of strain CIN1 ${ }^{T}$ indicated that it was a member of the low-G+C-containing Gram-positive branch with a specific relationship to Sporobacter termitidis (sequence identity of $\mathbf{8 8} \%$ ). The phylogenetic results concur with the phenotypic data which reveals that the isolate is a novel bacterium and, based on these

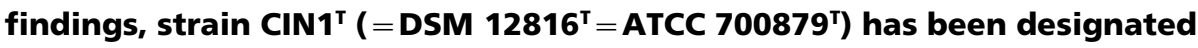
Papillibacter cinnamivorans gen. nov., sp. nov.

Keywords: Papillibacter cinnamivorans, anaerobes, aromatic compounds, transformation, cinnamate

\section{INTRODUCTION}

Lignin is the second most abundant natural product on earth and consists of a vast array of aromatic monomers including cinnamate (Collberg, 1988; Healy \& Young, 1979; Healy et al., 1980). It is now well established that monoaromatic compounds are attacked by a phylogenetically diverse range of anaerobic micro-organisms, some of which completely ferment the aromatic compounds and others that are only involved in transformation of such compounds. Pure cultures with the ability to ferment aromatic compounds include Coprococcus sp. (Patel et al., 1981), a

The GenBank accession number for the $16 \mathrm{~S}$ rDNA sequence of strain CIN1 ${ }^{\top}$ is AF167711. member of the low-G $+\mathrm{C}$-containing Gram-positive branch, Pelobacter acidigallici (Schink \& Pfennig, 1982) and Pelobacter massiliensis (Schnell et al., 1991), members of the Proteobacteria, which de-aromatize aromatic compounds such as gallate, resorcinol and phloroglucinol to produce acetate, Holophag a foetida (Liesack et al., 1994), a member of the Proteobacteria, and Sporobacter termitidis (Grech-Mora et al., 1996), a member of the low-G $+\mathrm{C}$-containing Gram-positive branch, are unusual in that they first transfer the etherlinked methyl groups to sulfide-producing methanethiol or dimethylsulfide followed by de-aromatization of the aromatic ring structure. Until recently, monohydroxylated aromatic compounds were considered undegradable by anaerobes, but recently Sporotomaculum hydroxybenzoicum (Brauman et al., 1998), a member of the low-G +C-containing Gram-positive 
branch, has been shown to degrade 3-hydroxybenzoate via the benzoyl-CoA pathway subsequent to the removal of the hydroxyl group. In other cases, dearomatization of the ring requires syntrophic coculture, as is the case with Syntrophus buswellii strain GA, a member of the Gram-negative Proteobacteria that degrades cinnamate under anaerobic syntrophic conditions only (Auburger \& Winter, 1995). The anaerobic members of Proteobacteria which transform aromatic compounds with ring cleavage include photosynthetic bacteria (some strains of Rhodopseudomonas palustris) (Harwood \& Gibson, 1988), sulfate-reducing bacteria (Desulfobacterium and Desulfococcus), metalreducing bacteria (Geobacter) and denitrifying bacteria (Thauera).

In this paper, the isolation and characterization of a new anaerobic bacterium, which transforms a limited range of aromatic compounds, namely cinnamate, 3methoxycinnamate and 4-methoxycinnamate, without de-aromatization of the ring are described. Physiological studies including metabolism of the substrates and end-products are reported.

\section{METHODS}

Source of strains. Strain CIN1 ${ }^{\mathrm{T}}$ was isolated from an anaerobic digester fed with shea cake situated in Burkina Faso (Africa). The digester had previously been inoculated with anaerobic sludge from the pit of a slaughterhouse. Carbon and energy sources were composed exclusively of tannins and aromatic compounds.

Culture media. A basal medium described below was used for enrichment, isolation and routine cultivation. The medium was prepared using the anaerobic technique described by Hungate (1969) and modified for use with syringes (Macy et al., 1972; Miller \& Wolin, 1974). The basal medium contained $\left(1^{-1}\right.$ deionized water $): 0 \cdot 2 \mathrm{~g} \mathrm{~K}_{2} \mathrm{HPO}_{4} ; 1 \mathrm{~g} \mathrm{NaCl}$; $0.15 \mathrm{~g} \mathrm{CaCl}_{2} .2 \mathrm{H}_{2} \mathrm{O} ; 0.4 \mathrm{~g} \mathrm{MgCl}_{2} .6 \mathrm{H}_{2} \mathrm{O} ; 0.5 \mathrm{~g} \mathrm{KCl} ; 0.5 \mathrm{~g}$ cysteine- $\mathrm{HCl} ; 0.5 \mathrm{~g}$ yeast extract; $1.5 \mathrm{ml}$ trace element solution (Widdel \& Pfennig, 1981); and $1 \mathrm{mg}$ resazurin. The $\mathrm{pH}$ was adjusted to $7 \cdot 0$ with a $10 \mathrm{M} \mathrm{NaOH}$ solution. The medium was then boiled under a stream of $\mathrm{O}_{2}$-free $\mathrm{N}_{2}$ gas and cooled to room temperature. Unless otherwise indicated, $5 \mathrm{ml}$ aliquots were dispensed into Hungate tubes under $\mathrm{N}_{2}-\mathrm{CO}_{2}(80: 2)$ gas mixture and subsequently sterilized by autoclaving at $110{ }^{\circ} \mathrm{C}$ for $45 \mathrm{~min}$. Prior to use, $0.2 \mathrm{ml} 5 \% \quad(\mathrm{w} / \mathrm{v}) \quad \mathrm{NaHCO}_{3}$ and $0.05 \mathrm{ml} 2 \% \quad(\mathrm{w} / \mathrm{v})$ $\mathrm{Na}_{2} \mathrm{~S} .9 \mathrm{H}_{2} \mathrm{O}$ were injected from anaerobic sterile stock solutions into the pre-sterilized basal medium.

Enrichment and isolation. The liquid digester sample $(0.5 \mathrm{ml})$ was inoculated into the basal medium emended with $5 \mathrm{mM}$ cinnamate and growth was followed by incubation at $37^{\circ} \mathrm{C}$. The enrichment culture that developed was subcultured several times under the same conditions. Subsequently, serial tenfold dilutions were prepared and inoculated into roll-tubes containing the basal medium supplemented with $5 \mathrm{mM}$ cinnamate and $1.6 \%(\mathrm{w} / \mathrm{v})$ agar. Several single wellisolated colonies that developed were picked, serially diluted in the anaerobic medium and the procedure was repeated at least three times. Several pure cultures were obtained, one of which was selected, designated strain $\mathrm{CIN1}^{\mathrm{T}}$, and characterized further. Purity was checked by microscopy of cultures grown in basal medium amended with $0.5 \%$ glucose and
$0.5 \%$ Biotrypcase; strain $\mathrm{CIN} 1^{\mathrm{T}}$ failed to grow under these conditions.

Light microscopy and electron microscopy. Light and electron microscopy were performed as described previously (Fardeau et al., 1997).

Growth studies. Substrates were added from sterile anaerobic stock solutions. All growth studies were conducted in duplicate unless otherwise indicated. The isolate was subcultured at least twice under the same experimental conditions. Growth studies were performed in basal medium containing $5 \mathrm{mM}$ cinnamate and $0.5 \mathrm{~g}$ yeast extract $1^{-1}$. For $\mathrm{pH}$ studies, the medium was adjusted to the required $\mathrm{pH}$ by injecting appropriate volumes from anaerobically prepared stock solutions of $1 \mathrm{M} \mathrm{HCl}, 10 \% \quad \mathrm{NaHCO}_{3}$ and $8 \%$ $\mathrm{Na}_{2} \mathrm{CO}_{3}$. Temperature range for growth was determined between 10 and $55^{\circ} \mathrm{C}$ using the basal medium adjusted to the optimum $\mathrm{pH}$. For studies on $\mathrm{NaCl}$ requirements, $\mathrm{NaCl}$ was weighed directly in the tubes to give the required concentration. For concentrations lower than $1 \%$, different aliquots of $10 \%(\mathrm{w} / \mathrm{v}) \mathrm{NaCl}$ were injected into predispensed basal medium to give the required concentration.

Sporulation test. Cells from various stages of the growth phase and from cultures grown on different substrates were observed microscopically for the presence of spores. In addition, the culture was tested for heat resistance. For this, cells grown in basal medium containing $5 \mathrm{mM}$ cinnamate were heated for $10 \mathrm{~min}$ at temperatures of 80,90 and $100{ }^{\circ} \mathrm{C}$. The cells were cooled quickly to ambient temperature, inoculated into fresh cinnamate-containing basal medium and growth was checked after at least 1 week incubation at $37^{\circ} \mathrm{C}$

Substrate utilization studies. For substrate utilization studies, the isolate was subcultured at least once under the same experimental conditions. Substrate utilization studies were performed in basal medium amended with one of the following substrates to give a final concentration as indicated: $5 \mathrm{mM}$ for all aromatic compounds including monomethoxylated aromatic compounds (2-, 3-, 4-methoxycinnamate), di-methoxylated aromatic compounds (2,3-, 2,4-, 2,5-, 2,6-, 3,5-dimethoxybenzoate, 3,5-dimethoxycinnamaldehyde), tri-methoxylated aromatic compounds (3,4,5-trimethoxybenzoate, 3,4,5-trimethoxycinnamate, 3,4,5-trimethoxyphenylacetate, 3,4,5-trimethoxyphenylpropionate), hydroxy-methoxylated aromatic compounds (ferulate, syringate and sinapate), mono-hydroxylated aromatic compounds (2-, 3-, 4- hydroxycinnamate, phenol and 4-hydroxybenzoate), polyhydroxylated aromatic compounds (caffeate, gallate, tyrosol, phloroglucinol, pyrogallol, catechol and hydroquinone), non-hydroxylated and non-methoxylated substituted cinnamyl derivatives $(\alpha$-methylcinnamate, methyl trans-cinnamate, cinnamyl alcohol, trans-cinnamate methyl ester and coumarine) and non-substituted aromatic compounds (cinnamate, benzoate, hydrocinnamate and phenylacetate); $10 \mathrm{mM}$ for organic acids (crotonate, pyruvate, succinate, malate, fumarate, propionate and butyrate); $10 \mathrm{mM}$ for carbohydrates (glucose, fructose, saccharose, ribose, xylose, cellobiose, maltose, galactose, mannose, lactose and arabinose); $5 \mathrm{mM}$ for alcohols (butanol, methanol and ethanol); and $0.5 \%(\mathrm{w} / \mathrm{v})$ for extracts (Biotrypcase, peptone, Casamino acids, gelatin and casein).

The utilization of a mixture of 2-, 3- and 4-methoxycinnamate $\left(3 \mathrm{mM}\right.$ and $5 \mathrm{mM}$ each) by isolate CIN1 $^{\mathrm{T}}$ was investigated. Utilization was evaluated by monitoring substrate disappearance and product accumulation. 
Electron acceptors. Thiosulfate, sulfate, sulfite and nitrate were tested as electron acceptors at a final concentration of $10 \mathrm{mM}$, whereas elemental sulfur and sodium fumarate were tested at a final concentration of $2 \%$ and $20 \mathrm{mM}$, respectively.

Analytical methods. Turbidity, as a measure of growth, was measured at $580 \mathrm{~nm}$ by inserting anaerobic Hungate tubes directly into the cuvette holder of a Shimadzu model UV 160A spectrophotometer. Aromatic compounds were measured using HPLC model 1100 (Hewlett Packard) equipped with a UV detector set at $240 \mathrm{~nm}$ and a 100position autosampler/autoinjector. Separation was achieved using a $\mathrm{C}_{18}$ SYMMETRY column $(4.6 \times 100 \mathrm{~mm}$, $3.5 \mu \mathrm{m}$ particle size; Waters Chromatography) maintained at $35^{\circ} \mathrm{C}$. The mobile phase consisting of a mixture of two solvents (water in $0.01 \%$ acetic acid and methanol) was used at a flow rate of $0.75 \mathrm{ml} \mathrm{min}{ }^{-1}$. For separation of aromatic compounds, $20 \%$ methanol solvent phase was initially held for $4 \mathrm{~min}$, then the concentration was increased to $40 \%$ over a period of $24 \mathrm{~min}$ followed by a wash for $6 \mathrm{~min}$, over which time the concentration of methanol was increased to $100 \%$. The column was re-equilibrated with $20 \%$ methanol for at least $5 \mathrm{~min}$ before the next injection. Quantification was performed using external standards.

Acetate and butyrate were measured by HPLC (Spectra Series 100 model; Thermo Separation Products) equipped with an Aminex HPX-87X column 300 by 7.8 mm (i.d.) (BioRad Laboratories) connected to a differential refractometer (RID-6A; Shimadzu). Analysis was performed using a CR6A Shimadzu integrator. The mobile phase was $0.0025 \mathrm{M}$ $\mathrm{H}_{2} \mathrm{SO}_{4}$ at a flow rate of $0.6 \mathrm{ml} \mathrm{min} \mathrm{mi}^{-1}$ and the column temperature was $35^{\circ} \mathrm{C}$. The volume of the injection loop was $20 \mu 1$.

$\mathbf{G}+\mathbf{C}$ content. DNA was isolated and purified and the $\mathrm{G}+\mathrm{C}$ content was determined by using HPLC as described by Mesbah et al. (1989) at the DSMZ (Deutsche Sammlung von Mikroorganismen und Zellkulturen, Braunschweig, Germany). Non-methylated lambda DNA (Sigma) was used as the standard.

DNA extraction and amplification of 16S rRNA gene. DNA was extracted from the isolate as described previously (Redburn \& Patel, 1993; Andrews \& Patel, 1996). The universal primers Fd1 and Rd1 were used to obtain a PCR product of approximately $1.5 \mathrm{~kb}$ corresponding to base positions 8-1500 based on Escherichia coli numbering of the 16S rDNA (Winker \& Woese, 1991). A $50 \mu$ reaction mix contained 1-20 ng genomic DNA, $1 \mu \mathrm{M}$ of each primer, $5 \mu \mathrm{l}$ $10 \times$ buffer, $200 \mu \mathrm{M}$ dNTP, $3.5 \mathrm{mM} \mathrm{MgCl}_{2}$ and $2.5 \mathrm{U}$ Taq polymerase (Promega). PCR was carried out by an initial denaturation at $94^{\circ} \mathrm{C}$ for $7 \mathrm{~min}$, then 29 cycles of annealing at $55^{\circ} \mathrm{C}$ for $2 \mathrm{~min}$, extension at $72^{\circ} \mathrm{C}$ for $4 \mathrm{~min}$, denaturation at $94^{\circ} \mathrm{C}$ for $1 \mathrm{~min}$, and finally an extension cycle of $55^{\circ} \mathrm{C}$ for $2 \mathrm{~min}$ and $72^{\circ} \mathrm{C}$ for $20 \mathrm{~min}$.

Direct sequencing of PCR products. PCR products were purified using the QIAquick kit (Qiagen). The DNA concentrations of purified PCR products were estimated by comparison with the Low Mass Ladder (Gibco-BRL) on an ethidium bromide-containing agarose gel. Sequencing was carried out using the ABI Dye Terminator Cycle Sequencing kit containing AmpliTaq FS DNA polymerase under the following conditions. A $10 \mu \mathrm{l}$ reaction mix contained $35 \mathrm{ng}$ PCR product, $4 \mu \mathrm{l}$ cycle sequencing reaction mix, $3 \cdot 2 \mathrm{pmol}$ primer (Andrews \& Patel, 1996) and 2.5 $\mu \mathrm{g}$ BSA. Thermal cycling was carried out using a Rapid Cycler (Idaho
Technology) at a temperature transition slope of 2 , an initial denaturation at $94{ }^{\circ} \mathrm{C}$ for $15 \mathrm{~s}$, then 25 cycles of denaturation at $94{ }^{\circ} \mathrm{C}$ for $0 \mathrm{~s}$, annealing at $50{ }^{\circ} \mathrm{C}$ for $10 \mathrm{~s}$, extension at $60{ }^{\circ} \mathrm{C}$ for $3 \mathrm{~min}$. The samples were purified from the unused dye terminators following the manufacturer's recommended procedures and sequenced using an ABI377 automated DNA sequencer (Applied Biosystems) at the Griffith University Molecular Biology Centre.

Sequence alignments and phylogenetic inferences. The new sequence data that were generated were assembled to an almost full-length consensus $16 \mathrm{~S}$ rRNA gene sequence and checked for accuracy manually using the alignment editor ae2 (Maidak et al., 1999). The new consensus sequence generated was compared with other sequences in the GenBank database (Benson et al., 1993) using BLAST (Altschul et al., 1997), and in the Ribosomal Database Project, version 7.0 using SIMILARITY-RANK and SUGGESTTREE (Maidak et al., 1999). Reference sequences most related to our newly generated sequence were extracted from the databases and aligned. Positions of sequence and alignment uncertainty were omitted from the analysis. Pairwise evolutionary distances based on 1392 unambiguous nucleotides were computed using DNADIST (Jukes \& Cantor option) and NEIGHBOR-JOINING programs that form part of the PHYLIP suite of programs (Felsenstein, 1993).

\section{RESULTS}

\section{Enrichment and isolation}

A cinnamate-enrichment culture was obtained after 3 weeks incubation at $37^{\circ} \mathrm{C}$. The enrichment culture was serially diluted and subcultured several times and resulted in the establishment of a stable microbial consortium that degraded cinnamate with concomitant production of acetate and benzoate. This consortium exhibited a morphologically dominant population of rod-shaped organisms which possessed characteristic terminal nipple-shaped ends. The enrichment culture was serially diluted and used to inoculate rolltubes. Single well-separated colonies that developed within incubation for 1 month were picked and the purification procedure was repeated several times until the cultures were deemed pure. A pure culture,

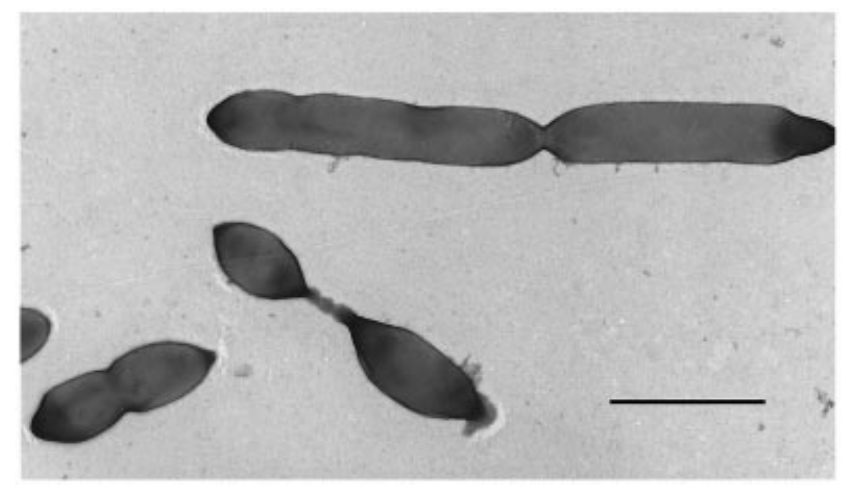

Fig. 1. Electron micrograph of cells of strain $\mathrm{CIN} 1^{\top}$ showing characteristic nipple-shaped pointed ends. Bar, $2 \mu \mathrm{m}$. 


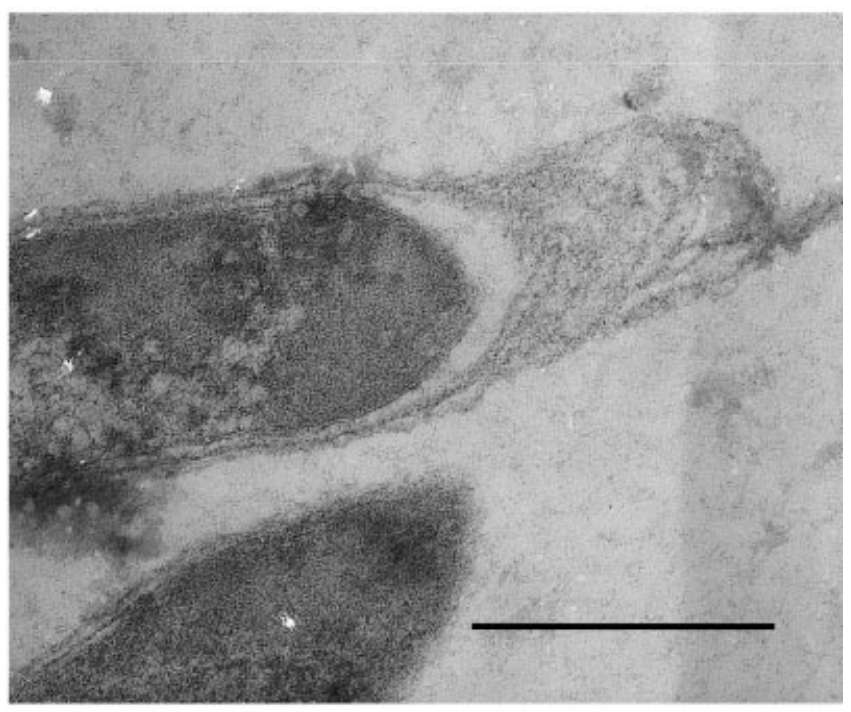

Fig. 2. Electron micrograph of a cell of strain $\mathrm{CIN} 1^{\top}$ showing terminal accumulation of an electron light surface layer (arrows). Bar, 0.5 $\mu \mathrm{m}$.

designated strain $\mathrm{CIN1}^{\mathrm{T}}$, was selected for further characterization.

\section{Cellular morphology}

Cells of strain $\mathrm{CIN}^{\mathrm{T}}$ were rod-shaped $(1 \cdot 3-3 \cdot 0 \times 0 \cdot 5-$ $0.6 \mu \mathrm{m})$ and had characteristic nipple-shaped pointed ends (Fig. 1a). The terminal nipple-shaped feature of strain $\mathrm{CIN} 1^{\mathrm{T}}$ lacked cytoplasmic material and appeared to be a part of the cell surface slime layer involved in the cell division process (Fig. 1b). The cells stained Gram-positive and ultrathin sections of strain CIN1 ${ }^{\mathrm{T}}$ showed a thin atypical Gram-positive-type cell wall with an external slime layer (Fig. 2). Motility was not observed and electron microscopic examination of negatively stained cells failed to reveal the presence of flagella. Spores were not observed. There was no cell growth after heat treatment indicating the lack of heatresistant bodies such as spores.

\section{Growth, physiological and metabolic properties}

The optimum growth temperature for strain $\mathrm{CIN} 1^{\mathrm{T}}$ was $37^{\circ} \mathrm{C}$ (growth was observed between 15 and $40{ }^{\circ} \mathrm{C}$ ), with no growth occurring at 10 and $45^{\circ} \mathrm{C}$. The optimum $\mathrm{pH}$ for growth was $\mathrm{pH} 7 \cdot 5$ ( $\mathrm{pH}$ growth range was 6.9-8.5) with no growth occurring at $\mathrm{pH} 6.0$ and $9 \cdot 0$. Strain $\mathrm{CIN} 1^{\mathrm{T}}$ did not require $\mathrm{NaCl}$ for growth but grew better in the presence of $0.5-1.0 \% \mathrm{NaCl}$, with no growth occurring in the presence of $2.0 \% \mathrm{NaCl}$.

Yeast extract was required for growth on cinnamate. Biotrypcase and casein, but not gelatin, stimulated growth but were not essential for growth and could not replace yeast extract. The rate of transformation of cinnamate did not change when yeast extract or

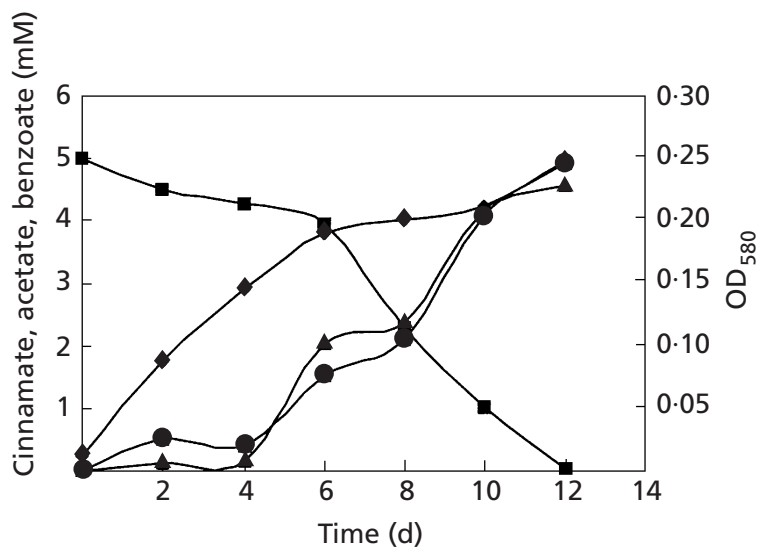

Fig. 3. Transformation of $5 \mathrm{mM}$ cinnamate by strain $\mathrm{CIN} 1^{\top}$. Growth is indicated by an increase in optical density ( $\diamond)$ and the transformation of cinnamate $(\boldsymbol{\square})$ to benzoate $(\boldsymbol{O})$ and acetate (A).

Biotrypcase concentrations were increased, although the cell yield increased.

Strain $\mathrm{CIN} 1^{\mathrm{T}}$ was unable to grow on any other substrates tested with the exception of cinnamate, 3methoxycinnamate, 4-methoxycinnamate and crotonate, as listed in the Methods.

Acetate and benzoate were produced from cinnamate transformation (Fig. 3), acetate and 3-methoxybenzoate were produced from 3-methoxycinnamate transformation, and acetate and 4-methoxybenzoate were produced from 4-methoxycinnamate transformation. Acetate and butyrate were produced from crotonate degradation.

The transformation of cinnamate was concentrationdependent (Table 1). With $15 \mathrm{mM}$ cinnamate, almost all the substrate was transformed. This is based on the observation that the ratios of benzoate: cinnamate and acetate: cinnamate were equal to 1 and are close to the calculated theoretical value of 1 . At concentrations above $15 \mathrm{mM}$, cinnamate was incompletely transformed with no transformation occurring above $30 \mathrm{mM}$, which can be considered as threshold toxicity for the isolate.

The results from studies on a $3 \mathrm{mM}$ mixture of each of 2-, 3- and 4-methoxycinnamate by strain $\mathrm{CIN} 1^{\mathrm{T}}$ indicated that the transformation of 3-methoxycinnamate had a shorter lag phase and occurred a bit faster than that of 4-methoxycinnamate (Fig. 4). The observation that the disappearance rates of the two isomers are different would suggest a positional selectivity for efficient transformation with regard to the methoxy group on the aromatic ring.

\section{Electron acceptors}

Sulfate, thiosulfate, sulfite, nitrate, elemental sulfur or fumarate were not utilized as electron acceptors. 
Table 1. Transformation of cinnamate at different concentrations by strain $\mathrm{CIN} 1^{\top}$

Basal medium supplemented with the various concentrations of cinnamate was used. Incubations were performed at $37^{\circ} \mathrm{C}$ for $14 \mathrm{~d}$, after which end products were analysed.

\begin{tabular}{|c|c|c|c|c|}
\hline \multirow{2}{*}{$\begin{array}{l}\text { Cinnamate } \\
(\mathrm{mM})\end{array}$} & \multicolumn{2}{|c|}{ Product formed (mM) } & \multicolumn{2}{|c|}{ Ratio of: } \\
\hline & Benzoate & Acetate & Benzoate: cinnamate & Acetate: cinnamate \\
\hline 5 & 5 & 4.94 & 1 & $0 \cdot 98$ \\
\hline 10 & 10 & $9 \cdot 98$ & 1 & 0.99 \\
\hline 15 & 15 & $14 \cdot 98$ & 1 & 0.99 \\
\hline 20 & $15 \cdot 36$ & $14 \cdot 23$ & $0 \cdot 76$ & $0 \cdot 71$ \\
\hline 25 & $13 \cdot 25$ & $13 \cdot 15$ & $0 \cdot 53$ & $0 \cdot 52$ \\
\hline 30 & $8 \cdot 95$ & $7 \cdot 56$ & $0 \cdot 29$ & $0 \cdot 25$ \\
\hline 35 & 0 & 0 & 0 & 0 \\
\hline
\end{tabular}

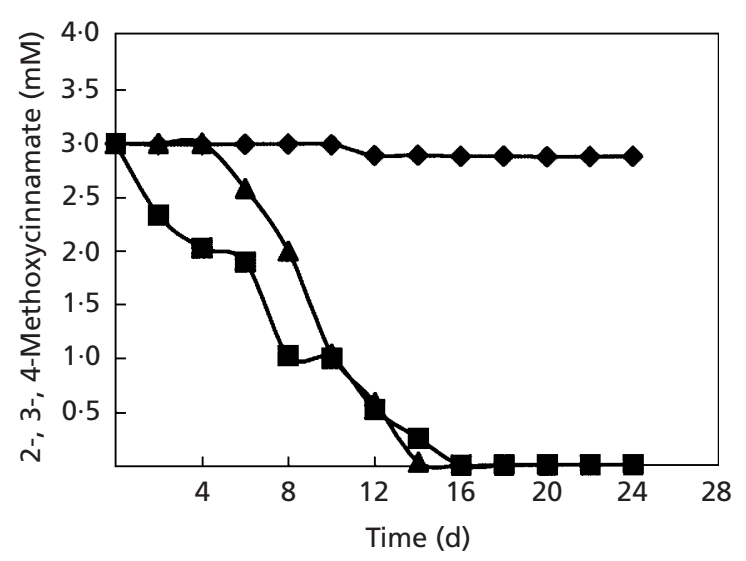

Fig. 4. The rate of disappearance of three different methoxylated cinnamates in the presence of strain $\mathrm{CIN}^{\top}{ }^{\top}$. The disappearance of 3-methoxycinnamate $(\boldsymbol{D})$ is much faster than that of 4-methoxycinnamate $(\boldsymbol{\Delta})$ whereas 2-methoxycinnamate $(\diamond)$ is not utilized.

\section{$\mathbf{G}+\mathbf{C}$ content}

The $\mathrm{G}+\mathrm{C}$ content of the DNA of strain $\mathrm{CIN}^{\mathrm{T}}{ }^{\mathrm{T}}$ was $56 \mathrm{~mol} \%$ as determined by HPLC.

\section{Phylogeny}

Using 12 primers, an almost complete sequence was determined consisting of $1492 \mathrm{nt}$ of the 16S rRNA gene of strain $\mathrm{CIN}^{\mathrm{T}}$ (corresponding to E. coli position 8-1500). Phylogenetic analysis (Fig. 5) revealed that strain CIN1 ${ }^{\mathrm{T}}$ was a member of cluster IV of the low$\mathrm{G}+\mathrm{C}$-containing Gram-positive branch as defined by Collins et al. (1994).

\section{DISCUSSION}

Physiologically, strain $\mathrm{CIN} 1^{\mathrm{T}}$ transforms aromatic compounds with a double bond in the $\mathrm{C}_{3}$-aliphatic side chain. The anaerobe Ruminococcus productus (for- merly Peptostreptococcus productus) transforms the aromatic compound ferulate by (a) $O$-demethylation and (b) reduction of the double bond of the $\mathrm{C}_{3}$ aliphatic side chain (Misoph et al., 1996), and the anaerobe Acetobacterium woodii reduces the double bond of the $\mathrm{C}_{3}$-aliphatic side chain of caffeate (Tschech et al., 1984). However, strain CIN $1^{\mathrm{T}}$ does not transform ferulate and caffeate but instead transforms cinnamate, an aromatic compound similar to ferulate and caffeate (both contain a double bond in the $\mathrm{C}_{3}$ aliphatic side chain) to benzoate and acetate. This trait of cinnamate transformation is also common to Rhodopseudomonas palustris and Syntrophus buswellii strain GA. However, strain $\mathrm{CIN1}^{\mathrm{T}}$ transforms cinnamate to produce acetate and benzoate which accumulates without further degradation, whereas a syntrophic co-culture of Syntrophus buswellii strain GA and Desulfovibrio vulgaris degraded cinnamate to produce acetate and $\mathrm{H}_{2} \mathrm{~S}$ without accumulation of benzoate. On the other hand, Rhodopseudomonas palustris requires light for cinnamate degradation but strain $\mathrm{CIN} 1^{\mathrm{T}}$ does not. Again, these traits indicate that strain $\mathrm{CIN}^{\mathrm{T}}$ is physiologically distinct from these two isolates.

Strain $\mathrm{CIN} 1^{\mathrm{T}}$ utilizes a very limited range of aromatic compounds which include cinnamate, 3-methoxycinnamate and 4-methoxycinnamate. Such a characteristic has not been reported previously and hence can be regarded as a new physiological feature. The transformation of 3-methoxycinnamate and 4methoxycinnamate but not 2-methoxycinnamate is also an interesting property of the new isolate and indicates stereospecific selection.

The closest phylogenetic neighbour to strain $\mathrm{CIN} 1^{\mathrm{T}}$ is Sporobacter termitidis, a member of cluster IV (Collins et al., 1994) of the low-G+C-containing Grampositive branch, with which it shares a sequence identity of $88 \%$. Based on this alone, strain $\mathrm{CIN1}^{\mathrm{T}}$ can be regarded as a member of a novel genus. In addition, there are numerous phenotypic differences which also 


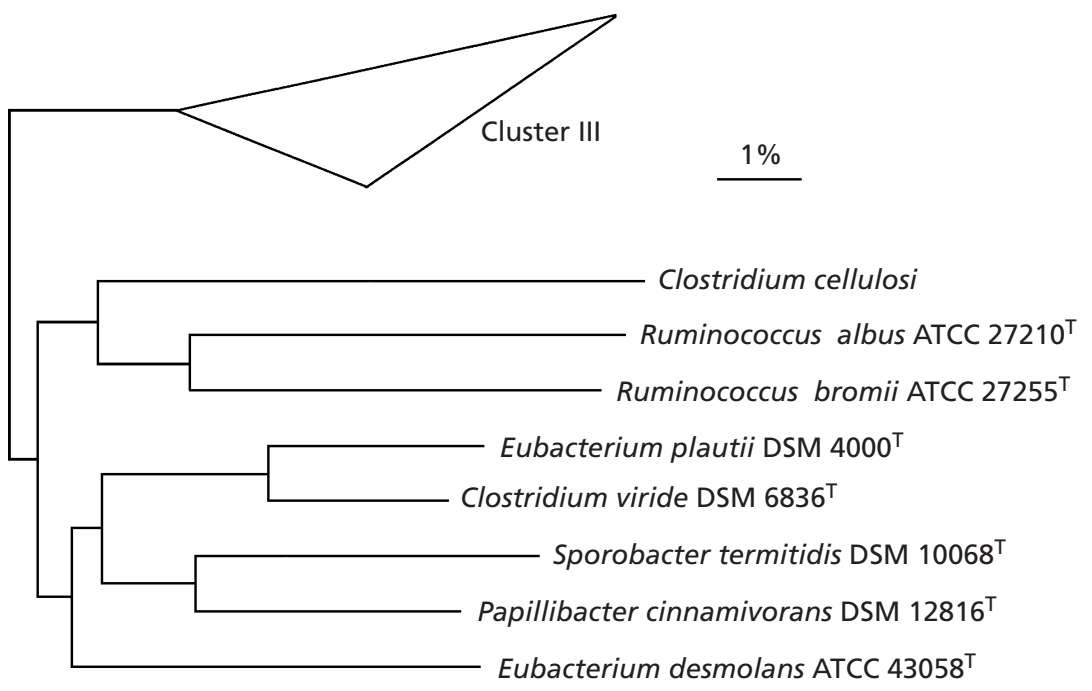

Fig. 5. Unrooted phylogenetic dendrogram based on 16S rRNA sequence data indicating the position of strain $\mathrm{CIN} 1^{\top}$ within the radiation of representatives of members of cluster III (indicated as a triangle consisting of Clostridium thermocellum, Clostridium termitidis, Clostridium cellulolyticum, Clostridium stercorarium, Clostridium thermolacticum and Acetivibrio cellulosolvens) and cluster IV consisting of the genus Clostridium and relatives according to Collins et al. (1994). All sequences used in the analysis were obtained from the Ribosomal Database Project, version 7 (Maidak et al., 1999). Evolutionary distances (based on 1321 unambiguous nucleotides) were computed using programs that form part of the PHYLIP package (Felsenstein, 1993). Scale bar, 1 nucleotide substitution per 100 nucleotides.

Table 2. Comparison of characteristics of strain $\mathrm{CIN} 1^{\top}$ and Sporobacter termitidis

\begin{tabular}{|c|c|c|}
\hline Characteristic & Strain CIN1 $^{\mathrm{T}}$ & Sporobacter termitidis* \\
\hline Morphology & $\begin{array}{l}\text { Rod shaped with pointed } \\
\text { ends }\end{array}$ & Slightly curved \\
\hline Size $(\mu \mathrm{m})$ & $0.5-0.6 \times 1.3-3.0$ & $0 \cdot 3-0.4 \times 1 \cdot 2$ \\
\hline Gram reaction & + & + \\
\hline Spores & - & + \\
\hline Motility & - & + \\
\hline pH optimum & $7 \cdot 5$ & $6 \cdot 7-7 \cdot 2$ \\
\hline $\mathrm{NaCl}$ optimum $\left(\mathrm{g}^{-1}\right)$ & $5-10$ & $0-5$ \\
\hline Temperature optimum $\left({ }^{\circ} \mathrm{C}\right)$ & 37 & $32-35$ \\
\hline Yeast extract requirement & + & + \\
\hline \multicolumn{3}{|c|}{ Growth on aromatic compounds: $\dagger$} \\
\hline Cinnamate & + & - \\
\hline 2-Methoxycinnamate & - & ND \\
\hline 3-Methoxycinnamate & + & ND \\
\hline 4-Methoxycinnamate & + & - \\
\hline 3,4,5-Trimethoxycinnamate & ND & + \\
\hline Sinapate & - & + \\
\hline 3,4-Dimethoxycinnamate & ND & + \\
\hline 3,4,5-Trimethoxybenzoate & - & + \\
\hline Ferulate & - & + \\
\hline Syringate & - & + \\
\hline Vanillate & - & + \\
\hline $\mathrm{G}+\mathrm{C}$ content $(\mathrm{mol} \%)$ & 56 & 57 \\
\hline
\end{tabular}

* Data from Grech-Mora et al. (1996).

$\uparrow$ Substrates tested but not used by both strains include the following: aromatic compounds (benzoate, phenylacetate, caffeate, gallate, phloroglucinol, pyrogallol, catechol, p-coumarate, phenol, 4-hydroxybenzoate), organic acids (pyruvate), carbohydrates (glucose, fructose, ribose, xylose, maltose, galactose, lactose) and alcohols (methanol, ethanol).

ND, Not determined.

set these two strains apart. Amongst these are the distinctly different morphologies and the range of substrates used (Table 2). Based on the evidence presented here, it is proposed that strain $\mathrm{CIN} 1^{\mathrm{T}}$ be designated a new species of a new genus, Papillibacter cinnamivorans gen. nov., sp. nov. 
Description of Papillibacter gen. nov.

Papillibacter (Pa.pil.li.bac'ter. L. fem. n. papilla teat; M.L. n. bacter masc. equivalent of Gr. neut. n. bakterion rod or staff; M.L. masc. n. Papillibacter a rod with ends looking like teat).

Cells are rod-shaped, occur singly, in pairs or in chains, and stain Gram-positive. No spores are formed and the cells are non-motile. Growth is strictly anaerobic. Growth is by degradation of a limited range of aromatic compounds and crotonate but not carbohydrates, organic acids or alcohols. Papillibacter represents a new line of descent in the low-G $+\mathrm{C}$-containing, Gram-positive branch based on 16S rRNA sequence analysis. The type species is Papillibacter cinnamivorans.

\section{Description of Papillibacter cinnamivorans sp. nov.}

Papillibacter cinnamivorans (cin.na.mi.vo'rans. M.L. n. cinnamum cinnamic acid; L. part. adj. vorans devouring, digesting; M.L. part. adj. cinnamivorans cinnamic-acid-digesting).

Cells are non-sporulating anaerobes which stain Gram-positive and are non-motile. The isolate utilizes cinnamate, 3-methoxycinnamate, 4-methoxycinnamate and crotonate. No growth occurs with the following substrates: mono-methoxylated aromatic compound (2-methoxycinnamate), di-methoxylated aromatic compounds $(2,3-, 2,4-, 2,5-$, 2,6-, 3,5dimethoxybenzoate, 3,5-dimethoxycinnamaldehyde), tri-methoxylated aromatic compounds $(3,4,5-$ trimethoxybenzoate, 3,4,5-trimethoxycinnamate, 3,4,5-trimethoxyphenylacetate, 3,4,5-trimethoxyphenylpropionate), hydroxy-methoxylated aromatic compounds (ferulate, syringate and sinapate), monohydroxylated aromatic compounds (2-, 3-, 4-hydroxycinnamate, phenol and 4-hydroxybenzoate), polyhydroxylated aromatic compounds (caffeate, gallate, tyrosol, phloroglucinol, pyrogallol, catechol and hydroquinone), non-hydroxylated and non-methoxylated substituted cinnamyl derivatives ( $\alpha$-methylcinnamate, methyl trans-cinnamate, cinnamyl alcohol, trans-cinnamate methyl ester and coumarine), nonsubstituted aromatic compounds (benzoate, hydrocinnamate and phenylacetate), organic acids (crotonate, pyruvate, succinate, malate, fumarate, propionate and butyrate), carbohydrates (glucose, fructose, saccharose, ribose, xylose, cellobiose, maltose, galactose, mannose, lactose and arabinose), alcohols (butanol, methanol and ethanol) or extracts (Biotrypcase, peptone, Casamino acids, gelatin and casein). Sulfate, thiosulfate, sulfite, nitrate, elemental sulfur or fumarate are not reduced. Optimum $\mathrm{pH}$ for growth is 7.5 (pH growth range 6.9-8.5). Optimal growth temperature is $37^{\circ} \mathrm{C}$ (temperature growth range $15-40^{\circ} \mathrm{C}$ ). Optimum growth occurs in the presence of $0.5-1 \cdot 0 \% \mathrm{NaCl}$, with no growth occurring in the presence of $2.0 \% \mathrm{NaCl}$. The $\mathrm{G}+\mathrm{C}$ content of the DNA is $56 \mathrm{~mol} \%$. The type strain is $\mathrm{CIN1}^{\mathrm{T}}$ $\left(=\mathrm{DSM} 12816^{\mathrm{T}}=\mathrm{ATCC} 700879^{\mathrm{T}}\right)$. Isolated from an anaerobic digester fed with shea cake, Burkina Faso.

\section{ACKNOWLEDGEMENTS}

We thank Tahar Mechichi for his critical reading of the manuscript, M.-L. Fardeau for her encouragement during this work and P. Thomas for assistance in electron microscopy. Funding in part to B. K.C.P. from the Australian Research Council is gratefully acknowledged.

\section{REFERENCES}

Altschul, S. F., Madden, T. L., Schäffer, A. A., Zhang, J., Zhang, Z., Miller, W. \& Lipman, D. J. (1997). Gapped BLAST and PSI-BLAST a new generation of protein database search programs. Nucleic Acids Res 25, 3389-3402.

Andrews, K. T. \& Patel, B. K. C. (1996). Fervidobacterium gondwanense sp. nov., a new thermophilic anaerobic bacterium isolated from nonvolcanically heated geothermal waters of the Great Artesian Basin of Australia. Int J Syst Bacteriol 46, 265-269.

Auburger, G. \& Winter, J. (1995). Isolation and physiological characterisation of Syntrophus buswellii strain GA from a syntrophic benzoate-degrading, strictly anaerobic coculture. Appl Environ Microbiol 44, 241-248.

Benson, D., Lipman, D. J. \& Olstell, J. (1993). GenBank. Nucleic Acids Res 21, 2963-2965.

Brauman, A., Muller, J. A., Garcia, J.-L., Brune, A. \& Schink, B. (1998). Fermentative degradation of 3-hydroxybenzoate in pure culture by a novel strictly anaerobic bacterium, Sporotomaculum hydroxybenzoicum gen. nov. sp. nov. Int J Syst Bacteriol 48, 215-221.

Collberg, P. J. (1988). Anaerobic microbial degradation of cellulose, lignin, oligolinols, and monoaromatic lignin derivatives. In Biology of Anaerobic Microorganisms, pp. 333-372. Edited by A. J. B. Zehnder. Chichester: Wiley Interscience.

Collins, M. D., Lawson, P. A., Willems, A., Cordoba, J. J., Fernandez-Garayzabal, J., Garcia, P., Cai, J., Hippe, H. \& Farrow, J. A. E. (1994). The phylogeny of the genus Clostridium: proposal of five new genera and eleven new species combinations. Int $J$ Syst Bacteriol 44, 812-826.

Fardeau, M.-L., Ollivier, B., Patel, B. K. C., Magot, M., Thomas, P., Rimbault, A., Rocchiccioli, F. \& Garcia, J.-L. (1997). Thermotoga hypogea sp. nov., a xylanolytic, thermophilic bacterium from an oil-producing well. Int J Syst Bacteriol 47, 1013-1019.

Felsenstein, J. (1993). PHYLIP (Phylogenetic Inference Package) version 3.51c. Distributed by the author. Department of Genetics, University of Washington, Seattle, USA.

Grech-Mora, I., Fardeau, M.-L., Patel, B. K. C., Ollivier, B., Rimbault, A., Prensier, G., Garcia, J.-L. \& Garnier-Sillam, E. (1996). Isolation and characterization of Sporobacter termitidis gen. nov., sp. nov., from the digestive tract of the wood-feeding termite Nasutitermes lujae. Int J Syst Bacteriol 46, 512-518.

Harwood, C. S. \& Gibson, J. (1988). Anaerobic and aerobic metabolism of diverse aromatic compounds by the photosynthetic bacterium Rhodopseudomonas palustris. Appl Environ Microbiol 54, 712-717.

Healy, J. B., Jr \& Young, L. Y. (1979). Anaerobic biodegradation of eleven aromatic compounds to methane. Appl Environ Microbiol 38, 84-89. 
Healy, J. B., Jr, Young, L. Y. \& Reinhard, M. (1980). Methanogenic decomposition of ferulic acid, a model lignin derivative. Appl Environ Microbiol 39, 436-444.

Hungate, R. E. (1969). A roll-tube method for the cultivation of strict anaerobes. Methods Microbiol 136, 194-198.

Liesack, W., Bak, F., Kreft, J. U. \& Stackebrandt, E. (1994). Holophaga foetida gen. nov., sp. nov., a new homoacetogenic bacterium degrading methoxylated aromatic compounds. Arch Microbiol 162, 85-90.

Macy, J. M., Snellen, J. E. \& Hungate, R. E. (1972). Use of syringe methods for anaerobiosis. Am J Clin Nutr 25, 1318-1323.

Maidak, B. L., Cole, J. R., Parker, C. T., Jr \& 11 other authors (1999). A new version of the RDP (Ribosomal Database Project). Nucleic Acids Res 27, 171-173.

Mesbah, M., Premachandran, U. \& Whitman, W. B. (1989). Precise measurement of the $\mathrm{G}+\mathrm{C}$ content of deoxyribonucleic acid by high-performance liquid chromatography. Int $J$ Syst Bacteriol 39, 159-167.

Miller, T. L. \& Wolin, M. J. (1974). A serum bottle modification of the Hungate technique for obligate anaerobes. Appl Microbiol 27, 985-987.

Misoph, M., Daniel, S. L. \& Drake, H. L. (1996). Bidirectional usage of ferulate by the acetogen Peptostreptoccocus productus $\mathrm{U}-1: \mathrm{CO}_{2}$ and aromatic acrylate groups as competing electron acceptors. Microbiology 142, 1983-1988.
Patel, T. R., Jure, K. G. \& Jones, G. A. (1981). Catabolism of phloroglucinol by the rumen anaerobe Coprococcus. Appl Environ Microbiol 42, 1010-1017.

Redburn, A. C. \& Patel, B. K. C. (1993). Phylogenetic analysis of Desulfotomaculum thermobenzoicum using polymerase chain reaction-amplified 16S rRNA-specific DNA. FEMS Microbiol Lett 113, 81-86.

Schink, B. \& Pfennig, N. (1982). Fermentation of trihydroxybenzenes by Pelobacter acidigallici gen. nov., sp. nov., a new strictly anaerobic, non-sporeforming bacterium. Arch Microbiol 133, 195-201.

Schnell, S., Brune, A. \& Schink, B. (1991). Degradation of hydroxyquinone by the strictly anaerobic fermenting bacterium Pelobacter massiliensis sp. nov.Arch Microbiol 155, 511-516.

Tschech, A. \& Pfennig, N. (1984). Growth yield increase linked to caffeate reduction in Acetobacterium woodii. Arch Microbiol 137, 163-167.

Widdel, F. \& Pfennig, N. (1981). Studies on dissimilatory sulfatereducing bacteria that decompose fatty acids. I. Isolation of new sulfate-reducing bacteria enriched with acetate from saline environments. Description of Desulfobacter postgatei gen. nov., sp. nov. Arch Microbiol 129, 395-400.

Winker, S. \& Woese, C. R. (1991). A definition of the domain Archaea, Bacteria and Eucarya in terms of small subunit ribosomal RNA characteristics. Syst Appl Microbiol 14, 305-310. 